\title{
Erratum to: News of a Hitherto Unknown Neo-Latin Columbus Epic, Part II. José Manuel Peramás's De invento Novo Orbe inductoque illuc Christi sacrificio (1777)
}

\author{
Maya Feile Tomes ${ }^{1,2}$
}

Published online: 28 October 2015

(C) Springer Science+Business Media Dordrecht 2015

\section{Erratum to: Int class trad (2015) 22(2):223-257 \\ DOI 10.1007/s12138-015-0374-2}

\section{Further points on Peramás: an Erratum and two Addenda}

The content of this note pertains to the study which I published, in two instalments, in this journal earlier this year: 'News of a Hitherto Unknown Neo-Latin Columbus Epic, Part I. José Manuel Peramás's De Invento Novo Orbe Inductoque Illuc Christi Sacrificio (1777)' and 'News of a Hitherto Unknown Neo-Latin Columbus Epic, Part II. José Manuel Peramás's De Invento Novo Orbe Inductoque Illuc Christi Sacrificio (1777)' ('Part I' and 'Part II' hereafter); ${ }^{1}$ it is above all the latter which shall concern us here. The De Invento Novo Orbe... (DINO) is an epic poem on the discovery and evangelization of the Americas, which-though its author, Spanishborn Jesuit José Manuel Peramás (1732-93), is reasonably well known to those in

\footnotetext{
${ }^{1}$ M. Feile Tomes, 'News of a Hitherto Unknown Neo-Latin Columbus Epic, Part I. José Manuel Peramás's De Invento Novo Orbe Inductoque Illuc Christi Sacrificio (1777)', International Journal of the Classical Tradition, 22.1 (2015), pp. 1-28, and 'News of a Hitherto Unknown Neo-Latin Columbus Epic, Part II. José Manuel Peramás's De Invento Novo Orbe Inductoque Illuc Christi Sacrificio (1777)', International Journal of the Classical Tradition, 22.1 (2015), pp. 223-57.
}

The online version of the original article can be found under doi:10.1007/s12138-015-0374-2.

Maya Feile Tomes

mcf37@cam.ac.uk

1 Faculty of Classics, University of Cambridge, Cambridge, UK

2 King's College, Cambridge, UK 
the relevant fields - had, for the reasons I explained in Part I, failed to attract any form of proper scholarly attention until then. Here, I offer three further points of information designed to be taken into account alongside the already published parts of the study, particularly when citing from them: an Erratum to rectify a mistaken impression given in one of the footnotes of Part II; a first Addendum in which I offer news of yet another hitherto unknown work by Peramás which has recently come to light, and which itself serves to alter previous conceptions of the chronology of Peramás's oeuvre; and a second Addendum regarding Peramás and his poetic predecessors in which I take up a claim already made in Part II, and record my intention to offer fuller consideration of the matter in the future.

\section{Erratum: Agustín Pomposo Fernández de San Salvador and Gian Rinaldo Carli}

The first point of information concerns the nineteenth-century Mexican material considered in Part II in connection with the early reception history of Peramás's DINO. The works in question are those of Mexican intellectual Agustín Pomposo Fernández de San Salvador (1756-1842), who mentions the DINO twice in publications produced in Mexico City in the early nineteenth century: ${ }^{2}$ once in his Los jesuitas quitados y restituidos al mundo of $1816,{ }^{3}$ and again in a footnote in a second work of 1822. The title of the latter work is Las cartas americanas. Nueva edición corregida y aumentada con la agregación de la parte tercera que ahora por primera vez se da impresa, ${ }^{4}$ itself the second instalment of the earlier volume of letters, Cartas americanas dirigidas por el Conde Gian-Rinaldo Carli a su sobrino el Marqués de Pietra-Pelosa, desde el año de 1777 al de 1779, released by Fernández de San Salvador in Mexico City the year before. ${ }^{5}$ In Part II of my study, I referred to the instalment of 1822 (Las cartas americanas. Nueva edición...) as both 'curious' and 'eccentric'. 6 In fact, for the purposes of a piece on Peramás, the primary point of 'curiosity' still stands: on an unnumbered leaf about two thirds of the way through the volume, ${ }^{7}$ there appears a title page announcing the translation of a work by Peramás (not of the DINO but rather of Peramás's most famous work, the De administratione guaranica comparata ad Rempublicam Platonis commentarius of 1793$) ;{ }^{8}$ however, the text which then follows is not actually a

\footnotetext{
2 The matter of A. P. Fernández de San Salvador's references to the DINO is important as they constitute essential early 19th-century evidence for the DINO's transmission to the Americas, as also for its reception history generally.

3 A. P. Fernández de San Salvador, Los jesuitas quitados y restituidos al mundo, Mexico City, 1816.

4 A. P. Fernández de San Salvador, Las cartas americanas. Nueva edición corregida y aumentada con la agregación de la parte tercera que ahora por primera vez se da impresa, Mexico City, 1822. See Part II (n. 1 above), nn. 25, 28 and 31; and see further below.

5 A. P. Fernández de San Salvador, Cartas americanas dirigidas por el Conde Gian-Rinaldo Carli a su sobrino el Marqués de Pietra-Pelosa, desde el año de 1777 al de 1779, Mexico City, 1821. See further Part II (n. 1 above), nn. 28 and 31.

${ }^{6}$ Part II (n. 1 above), pp. 231 and 232, n. 34.

7 See description in Part II (n. 1 above), pp. 231-2.

${ }^{8}$ See Part I (n. 1 above), p. 2.
} 
translation of the De adminstratione at all, but rather simply five more letters-a fact which does not appear to have been realised by such scholars and librarians as have ever turned their attention to it, all of whom take the extraneous title page at face value and list Fernández de San Salvador's 1822 work as containing the author's own translation of Peramás's treatise. ${ }^{9}$

However, as I noted at the time, the whole matter of Fernández de San Salvador's works of 1821 and 1822 clearly required further investigation, and this has indeed proved to be the case: no sooner was Part II published than an error in one of its footnotes came to my attention, which I am pleased to have the opportunity to rectify here. Following what now turns out to have been a misleading entry record in the catalogue of the British Library which I was unable to look into further at the time (I too have been guilty of taking at face value!), ${ }^{10} \mathrm{I}$ had stated that it also appears-though the matter requires further investigation-that the rest of the material in both Fernández de San Salvador['s work of 1822 and also, by association, that of 1821], purporting to be letters translated from the Italian, was, in fact, made up by Fernández de San Salvador himself'. ${ }^{11}$ However, having now had the chance to look into the matter further, I can report that this impression is quite mistaken: Fernández de San Salvador's works of 1821 and 1822 are indeed Spanishlanguage translations of the Lettere americane of Italian intellectual Gian Rinaldo Carli (1720-95), ${ }^{12}$ just as he says that they are; though in fact even better than 'translation' might be 'edition', for Fernández de San Salvador supplies his own introductory and concluding remarks, as well as extensive textual annotations (and even entire intercalated episodes in the main body of the text itself): crucial for our purposes, for it means that the footnoted reference to-and general interest in-

\footnotetext{
9 See Part II (n. 1 above), p. 232, with n. 33. In addition to the items mentioned there, note that the catalogue entries of not only the Biblioteca Nacional de México (BNM) but also of the Biblioteca Nacional de España (BNE) and of WorldCat all describe Fernández de San Salvador's Las cartas americanas (n. 4 above) as containing a translation of the De administratione, said to run from pp. 89-150 (which in reality is simply occupied by the remaining five letters). In the case of the BNE and WorldCat, moreover, it is also explicitly listed as having its own frontispiece ('con portada propia'), which is precisely the problem with this red herring of a title-page. (The BNM, BNE and WorldCat online catalogues featuring these descriptions were all last accessed: 23 September 2015.)

10 The description in the British Library's catalogue reads: 'Cartas Americanas dirigidas por el Conde Gian-Rinaldo Carli á su sobrino ... desde el año de 1777 al de 1779. Traducidas del Italiano [or rather written] por D. F. Pimentel Ixtliulxuchilt [sic]. Bajo cuyos nombres ... se ocultaba ... A. Pomposo Fernandez de San Salvador' (my emphasis). It was this English-language interjection in the midst of the Spanish title which initially led me to believe-and then, by association, to extend the erroneous idea to Fernández de San Salvador's work of 1821 as well — that there must be grounds to think that the works in question were not really the translations from the Italian that they purported to be. (The online catalogue of the British Library featuring the description in question was last accessed: 23 September 2015.)

11 Part II (n. 1 above), p. 232, n. 34.

12 See further 'Carli's American Letters' in A. Gerbi, The Dispute of the New World: The History of a Polemic, 1750-1900, transl. J. Moyle, Pittsburgh, 2010, pp. 233-9; also 'Gian Rinaldo Carli's Lettere Americane and the Apotheosis of Utopia' in S. Buccini, The Americas in Italian Literature and Culture 1700-1825, transl. R. Giammanco, Pennsylvania, 1997, pp. 76-83.
} 
Peramás's DINO in the publication of 1822 is, as originally stated, ${ }^{13}$ indeed Fernández de San Salvador's own ${ }^{14}$ _not Carli's.

Gian Rinaldo Carli's Lettere americane-emphatically pro-American documents (hence Fernández de San Salvador's interest in making them available for a Mexican readership) defending indigenous American achievement and culture at a time when continental Europe was wracked with polemic on the subject-were first published in Italy in the later eighteenth century, themselves in different instalments: parts one (25 letters) and two (a total of 19 letters) were issued as separate items in Florence in $1780,{ }^{15}$ and then a complete edition-containing the aforementioned two and also a new third part (12 letters) - appeared in Cremona in 1781. ${ }^{16}$ Fernández de Salvador, however, does not offer a full translation: instead, for reasons he himself explains in his introductory note, ${ }^{17}$ his first instalment of 1821 contains just eight letters (nos. 13-20) excerpted from the first part of Carli's epistles (though clearly, at the time of preparing this issue, he did know the complete, three-part edition of collected letters, for he refers to it), ${ }^{18}$ while the publication of 1822 contains the full twenty-five letters of Part One of Carli's work: first 1-12, then the insert of 13-20 as published on its own the year before, ${ }^{19}$ then 21-5. In passing, therefore, one may take this opportunity to note a new point of curiosity: from the title of Fernández de San Salvador's instalment of 1822, one would never know that it featured only Part One of Carli's letters, ${ }^{20}$ for he has retained the full title as it appeared in the three-part edition of 1781 (Le lettere americane. Nuova edizione corretta ed ampliata colla aggiunta della parte III. ora per la prima volta impressa, faithfully rendered as Las cartas americanas. Nueva edición corregida y aumentada con la agregación de la parte tercera que ahora por primera vez se da impresa), though it does not actually contain the new third part at all-and nor, for that matter, the second part either.

What it does contain, however, is the mysterious title page announcing the translation of Peramás's De adminstratione, which appears on a numberless leaf between the end of the insert containing letters 13-20, and the commencement of letter 21. (Note that in my discussion in Part II, I had erroneously construed the 'parte tercera' in the phrase 'parte tercera que ahora por primera vez se da

\footnotetext{
13 Part II (n. 1 above), pp. 230-1, 232-3.

14 As he himself explains, Carli's original notes to the text are designated with letters and his own annotations with numbers-Fernández de San Salvador, Las cartas americanas (n. 4 above), p. 1, n. 1and this is a numbered note: Las cartas americanas (n. 4 above), p. 14, n. 8.

15 G. R. Carli, Delle lettere americane: parte prima, Cosmopoli, 1780, and Delle lettere americane: parte seconda, Cosmopoli, 1780.

${ }^{16}$ G. R. Carli, Le lettere americane. Nuova edizione corretta ed ampliata colla aggiunta della parte III. ora per la prima volta impressa, Cremona (per Lorenzo Manini-Regio Stampatore), 1781.

17 Fernández de San Salvador, Cartas americanas (n. 5 above), '1 a Advertencia'.

18 Indeed, not only does he refer to it in the introduction (see n. 17 above), but also uses a portion of its preface as the 1821 work's epigraph.

19 As such, Fernández de San Salvador's publication of 1821 really does constitute a kind of 'before-thefact' supplement, as I said at Part II (n. 1 above), p. 231, n. 28. See also Part II (n. 1 above), p. 231, n. 31.

${ }^{20}$ C. Radicati di Primeglio, Juan Reinaldo Carli: economista y americanista del siglo XVIII, Lima, 1944, p. 27, also noted this oddity.
} 
impresa' as a reference to this 'phantom translation' of the De adminstratione which 'begins' two thirds of the way through, when in reality it is simply_if curiously-a direct translation of the title of the 1781 original.) As discussed in Part II, Fernández de San Salvador does make an oblique reference in the epilogue of the insert of 1821 to releasing a work which can only be Peramás's De adminstratione, ${ }^{21}$ and so it would seem reasonable to conclude that the title-page which then features is a form of sample frontispiece designed to illustrate, and presumably to whet the appetite for, the work to which he was referring. ${ }^{22}$ Unfortunately, however, there is no note to this effect attaching to the title-page itself ${ }^{23}$ - hence the problems for librarians the world over. The misrepresentation of Fernández de San Salvador's work in my own study may now have been cleared up, therefore; but the circumstances surrounding the phantom translation of the De administratione continue, as before, to require further investigation.

\section{Addendum 1: A(nother) new publication by Peramás}

The first half of 2015 turns out to be have been a good season for Peramás studies: while I was busy in the library in Faenza with the papers which would turn out to include the new poem by Peramás-In conciones, quas habuit $C l$. V. D. Vincentius Guerrinius Canonicus Ecclesiae Senogalliensis, alteram de inferno, alteram de conscientiae stimulis, qui peccantem torquent: Idyllium-of which I made first mention in the postscript to Part II, ${ }^{24}$ at almost exactly the same time in the neighbouring town of Forlì another unknown piece was in the process of being uncovered by Italian scholar, Fabrizio Melai; it is with his permission, and that of the curator of the library collection in question, that I report what follows.

The new item in question is a short poem, in twelve elegiac couplets, printed on a single oversized sheet at the press of Josephus Antonius (Giuseppe Antonio or Gioseffantonio) Archi in Faenza. ${ }^{25}$ The only presently known copy is that in the Biblioteca Comunale in Forlì. ${ }^{26}$ The poem, in which Peramás identifies himself as the author at the end with the words 'Josephus Peramasius canebat', is entitled Clarissimo et nobilissimo viro Com. Antonio Severoli quod VI. Idus Febr. an. MDCCLXXIV extractis in noctem ludis hastilibus media inter funalia vicerit-

\footnotetext{
$\overline{21}$ Fernández de San Salvador, Cartas americanas (n. 5 above), pp. 83-4.

22 Note that the title page only features in the longer (1822) version of Fernández de San Salvador's work (n. 4 above), not that of 1821 (n. 5 above), although it is in the latter that the oblique mention to the $D e$ administratione first appears: see n. 21 above.

23 There is a translator's note on the verso side, but-though it does make mention of the Jesuits and Paraguay - it does not offer any sort of explanation regarding the presence or significance of the title page on the recto.

24 Part II (n. 1 above), pp. 256-7.

25 The press of Archi is where practically all Peramás's works published in Italy were printed, with the exception of his poem of 1787-see Part I (n. 1 above), p. 9, nn. 28-9, with Part II (n. 1 above), p. 245, n. 68-and possibly the Idyllium, for which it has not yet been possible to establish the place of publication conclusively: see further Part II (n. 1 above), pp. 256-7, and nn. 28 and 33 below.

26 The precise location of the item is: Biblioteca Comunale Forlì, Raccolte Piancastelli, Sez. Carte Romagna, 443.138.
} 
Epigramma: an 'epigram' dedicated to local count Antonio Severoli to celebrate his triumph in a horse race. ${ }^{27}$ Like the Idyllium, therefore, it is an occasional poem; unlike the Idyllium, ${ }^{28}$ however, the Epigramma conserves its original date of publication: $1774 .^{29}$ The emergence of this new item is thus significant not only in that it represents a hitherto unknown work by our Jesuit with which we can add to the steadily increasing register of his works, and perhaps also in that it offers a small insight into the local society and structures of patronage into which the IberoAmerican exiles slotted themselves after arrival in Faenza, but, above all, because its date of 1774 means that its publication preceded that of the DINO-published in 1777-by three years. ${ }^{30}$ Prior to the re-emergence of the Epigramma, no Peramasian work printed in Italy in the first part of the 1770s was known, leading me to assert in both Parts $\mathrm{I}$ and $\mathrm{II}^{31}$ that the DINO had the distinction of being not only Peramás's first printed verse work but also his first work of any genre to have been published (though not, of course, composed) ${ }^{32}$ in Italy. The existence of a published (verse) work-however short-from 1774 thus puts paid to both these notions. ${ }^{33}$ At the same time, however, though the DINO no longer boasts the distinction of being Peramás's first work-nor even just his first verse work-to be published upon arrival in Italy, the two recently uncovered pieces (106-line Idyllium

\footnotetext{
${ }^{27}$ However, despite the obstacle of the apparently unrelated subject matter, not to mention of the poem's extreme brevity, Peramás nevertheless manages to squeeze in what one might call a fleeting allusion to the New World: in the ninth couplet, the Sun is described as fleeing to the 'Antipodum littora'.

28 The Idyllium was originally printed in some sort of anthology but the only currently known copy of the poem - that in the library in Faenza - has been excerpted from its original context and pasted into a handbound volume, divorcing it from the paratextual material which would have indicated its original date and place of publication. At the time of writing, it has not yet possible to establish the date by other means; see further n. 33 below.

29 The year 1774 is mentioned not only in the title of the work itself but also along with the date and place of publication: Faventiae (Faenza), Typis Josephi Antonii Archi, 1774.

${ }^{30}$ It thus also constitutes a further piece of information to belie twentieth-century Jesuit historian Miquel Batllori's notion-itself already belied by the DINO of 1777: see discussion at Part II (n. 1 above), p. 241, n. 62-that Peramás did not do any literary composition whatsoever during his early years in Italy, beginning to do so 'only in the last years of his life' (Peramás died in 1793). Note, however, thatcontrary to what I said in Part II (n. 1 above), p. 241, n. 62-Batllori's volume of 1966 does feature a reference to the DINO, albeit only later on (M. Batllori, La cultura hispano-italiana de los jesuitas expulsos: españoles, hispano-americanos, filipinos, 1767-1814, Madrid, 1966, p. 586), not in the chapter dedicated to Peramás in particular: at the time of preparing the latter (originally published in Italian in 1938, and then included again-in translated, but apparently otherwise unrevised, form-in Batllori's collected volume of 1966), Batllori indeed seems, as I said, to have been unaware of (or forgotten to mention) the DINO's existence.

31 Part I (n. 1 above), pp. 8, 9; Part II (n. 1 above), p. 224.

32 Peramás composed two exile diaries-one in Spanish and one in Latin-of which the latter was prepared, and the former completed, in Italy. He may also have been at work on other things prior to 1774 as well.

33 Conceivably they might also come to be belied by the Idyllium, were the emergence of further information about "Vincentius Guerrinius" to enable us to date it and were that date to prove to be prior to 1777 as well; but at present details of the identity of Vincentius Guerrinius, the canon from Senigallia, and the occasion of his conciones, remain unclear and require further investigation. One might note, however, that "Vincentius Guerrinius" is also the name associated with the Pontificale Romanum Summorum Pontificum jussu editum a Benedicto XIV. Pont. Max. ..., produced in 1818-19 in Urbinojust $40 \mathrm{~km}$ from Senigallia: could there be a connection?
} 
and 24-line Epigramma) cannot be said even remotely to approach the stature of the DINO: Peramás's three-book-2,373-line-Columbus epic. The DINO thus remains, even if not the first to be published in Italy, easily the most significant known verse work published by our author ${ }^{34}$-at any time. ${ }^{35}$

\section{Addendum 2: Giulio Cesare Stella's Columbeis and Peramás's DINO}

Lastly, I am pleased to have the opportunity to offer a brief word-in reality, advance notice of future work-on Peramás and his sixteenth-century Columbus epicist predecessor, Giulio Cesare Stella. One of the outstanding questions in Part II was the matter of whether or not Peramás knew Stella's Columbeis (1585/89), the earliest of the Virgilian-style Neo-Latin Columbus epics. Peramás himself never refers to Stella: of four knowable Columbus epicist predecessors, he refers to just two, and Stella is not one of them. However, as discussed in Part II, the question of Stella's omission is not so simple: not only is there the matter of a strangely misquoted remark which ought rightly to have referred to him, but also, more importantly, there are numerous episodes and turns of phrase in the DINO- of which only a couple were tentatively recorded in Part II (pp. 246 and 250, n. 78) which put one distinctly in mind of the Columbeis. Since the publication of Part II, further parallels have come to my attention of a verbal closeness so striking that they would appear to demonstrate conclusively that Peramás must—despite his own silence on the matter, and contrary to the recent conclusion of D. Arbo and A. Laird (see Part II, p. 236, n. 43) -indeed have known the Columbeis. This in turn promotes the previously noted correspondences from tentative possibilities to seriously suggestive allusions in their own right, as well as licensing a more sustained effort to consider the nature of the connection between the two works and inviting proper analysis of their similarities and also, perhaps more significantly still, their differences. The matter of the misquoted remark-which may simply be a lapsus, but if not a lapsus then, one can only assume, something more deliberatealso swells in importance in the light of the new evidence. Fuller discussion will be the subject of a separate note.

\footnotetext{
34 Peramás's only other substantial published verse work (at least as far as we know) is the Adveniente Faventiam illustrissimo ac reverendissimo episcopo... of 1787 , another occasional verse composition, which - though much longer than either the Idyllium or Epigramma - is still far more modest in scale than the DINO. On the Adveniente Faventiam, see Part I (n. 1 above), p. 9. Note that I refer here to published works: Peramás did also compose other verse works which did not see the light of publication, including one which - if reports are to be believed-was at least two or three times longer than the DINO itself; see, again, Part I (n. 1 above), pp. 9-11.

35 I would like to thank Fabrizio Melai for alerting me to the existence of the new poem in Forlì and generously sharing his transcription of it with me; Antonella Imolesi, director of the rare books collections in the Biblioteca Comunale "Aurelio Saffi" in Forlì (and helpful correspondent on various topics over the past two years), for speedily furnishing me with a copy of the document itself; and the production team of this journal for enabling me to supply this note so quickly.
} 